\title{
Inkluzywny potencjał globalnej edukacji obywatelskiej
}

\section{STRESZCZENIE}

Wraz z ogłoszeniem przez ONZ „Agendy na rzecz zrównoważonego rozwoju 2030” globalna edukacja obywatelska stała się ważnym narzędziem realizacji Celów Zrównoważonego Rozwoju. Jednym z jej zadań jest w ujęciu UNESCO przygotowanie dzieci, młodzieży i dorosłych do budowy bardziej inkluzywnego świata. Krytycy podkreślają jednak, że wiele działań z zakresu globalnej edukacji obywatelskiej ma charakter pozornie inkluzywny. Problematyczny okazuje się konstrukt globalnego obywatela - elitarny, imperialistyczny i paternalistyczny, a także ucieleśniający dyskurs neoliberalny.

Celem artykułu jest analiza inkluzywnego potencjału globalnej edukacji obywatelskiej i wskazanie możliwych ścieżek poszerzenia go. Argumentuję, że aby uczynić globalną edukację obywatelską bardziej inkluzywną, warto przeformułować kategorię globalnego obywatelstwa. Odwołując się do prac R. Lister, V. Andreotti, A. Abdiego czy L. Shultz proponuję bardziej elastyczną, pluralistyczną formułę globalnego obywatelstwa, wrażliwego na różnicę, ale nie rezygnującego z uniwersalistycznych obietnic. Nakreślam także wybrane implikacje tej formuły dla globalnej edukacji obywatelskiej.

\section{Słowa kluczowe:}

globalna edukacja obywatelska, inkluzja, globalne obywatelstwo, inkluzywne obywatelstwo

1 Magdalena Kuleta-Hulboj, Wydział Pedagogiczny, Uniwersytet Warszawski, Polska, e-mail: m.kuleta-hulboj@uw.edu.pl. 


\begin{abstract}
With the UN “Agenda for Sustainable Development 2030”, global citizenship education has become an important tool for achieving the Sustainable Development Goals. According to UNESCO, its aim is to prepare children, youth and adults to build more inclusive world. Critics, however, emphasise that many activities in the field of global citizenship education are only seemingly inclusive. The construct of a global citizen - elitist, imperialist and paternalistic, as well as embodying the neoliberal discourse - turns out to be problematic.

The aim of this article is to analyse the inclusive potential of global citizenship education and to point out some possible ways of expanding it. I argue that to make global citizenship education more inclusive, there is a need to reformulate the concept of global citizenship. Drawing on the works of R. Lister, V. Andreotti, A. Abdi and L. Shultz, I propose a more flexible, pluralistic formula of global citizenship, sensitive to difference but not giving up universalist promises. I also outline the implications of this formula for global citizenship education.
\end{abstract}

\title{
Keywords:
}

global citizenship education; inclusion; global citizenship; inclusive citizenship

\section{WPROWADZENIE}

Globalna edukacja obywatelska, rozumiana jako edukacja przygotowująca dzieci, młodzież i dorosłych do pełnienia aktywnej roli w budowaniu bardziej sprawiedliwego i bezpiecznego świata na poziomie lokalnym i globalnym (UNESCO, 2014, s. 15), w ostatnich latach cieszy się rosnącym zainteresowaniem. W wielu krajach wdrażane są kolejne inicjatywy edukacyjne kształtujące umiejętności uważane za niezbędne do życia w globalizującym się świecie. Uniwersytety opracowują strategie i polityki umiędzynarodowienia, wplatając w nie dyskursy globalnego obywatelstwa (Kraska, Bourn, Blum, 2018), a organizacje pozarządowe realizują coraz to nowe projekty kształtujące globalnych obywateli.

Popularność globalnej edukacji obywatelskiej wzrosła między innymi dzięki działalności ONZ i UNESCO, które uczyniły ją jednym ze strategicznych narzędzi Celów Zrównoważonego Rozwoju. Wśród 17 celów dotyczących najważniejszych wyzwań globalnych znalazł się także cel 4. traktujący o dobrej jakości edukacji. Jest w nim mowa o zapewnieniu wszystkim ludziom na świecie edukacji włączającej na wysokim poziomie oraz o promowaniu uczenia się przez całe życie. Poza 
licznymi zadaniami szczegółowymi pojawia się także jedno odnoszące się wprost do globalnej edukacji obywatelskiej: „Do 2030 roku zapewnić, że wszyscy uczący się nabędą wiedzę i umiejętności potrzebne do promowania zrównoważonego rozwoju, w tym, między innymi, poprzez edukację na rzecz zrównoważonego rozwoju i zrównoważonego stylu życia, praw człowieka, równości płci, promowania kultury pokoju i niestosowania przemocy, globalnego obywatelstwa i uznania wartości różnorodności kulturowej oraz wkładu kultury do zrównoważonego rozwoju” (ONZ, 2015).

UNESCO uczyniło globalną edukację obywatelską jednym z kluczowych celów edukacyjnych na lata 2014-2021, a w kwietniu 2015 roku przyjęło rezolucję, która wzywa państwa członkowskie do podejmowania programów i polityk na jej rzecz (jako jednego z czynników realizacji Celów Zrównoważonego Rozwoju). Globalna edukacja obywatelska według UNESCO to „model edukacji rozwijającej wiedzę, umiejętności, wartości i postawy potrzebne do tworzenia bardziej sprawiedliwego, pokojowego, tolerancyjnego, inkluzywnego, bezpiecznego i zrównoważonego świata” (UNESCO, 2014, s. 9). Inkluzja społeczna jest więc jednym z celów globalnej edukacji obywatelskiej w ujęciu UNESCO. Do zadań szczegółowych należy rozwijanie takich kompetencji, jak: wiedza o wyzwaniach globalnych i „uniwersalnych wartościach, takich: jak sprawiedliwość, równość, godność i szacunek" (UNESCO, 2014, s. 17); rozumienie, że tożsamości indywidualne i społeczne są konstruktami wielowymiarowymi; myślenie krytyczne i kreatywne oraz umiejętność analizowania problemów z wielu perspektyw; umiejętności społeczne i komunikacyjne; odpowiedzialna współpraca z innymi dla wspólnego dobra (UNESCO, 2014).

Mimo że dążenie do bardziej inkluzywnego świata jako zadanie globalnej edukacji obywatelskiej jest explicite artykułowane w dokumentach ONZ, UNESCO oraz w innych programach politycznych i edukacyjnych, krytycy wskazują, że wiele działań z tego zakresu ma charakter pozornie inkluzywny (Andreotti, 2016; Jefferess, 2008). Dzieje się tak z różnych powodów. Jednym z nich jest sam ideał globalnego obywatela, który - paradoksalnie - wytwarza nowe wymiary wykluczenia (omawiam je w dalszej części tekstu).

Celem artykułu jest analiza inkluzywnego potencjału globalnej edukacji obywatelskiej i wskazanie możliwych ścieżek pogłębienia i poszerzenia go. Teza jest następująca: by uczynić globalną edukację obywatelską bardziej inkluzywną, warto przeformułować kategorię globalnego obywatelstwa, w czym inspirujące mogą być między innymi prace Ruth Lister dotyczące inkluzywnego obywatelstwa. Zanim przejdę do argumentacji przyjętego stanowiska, wyjaśnię podstawowe kategorie i założenia, na których opiera się dalszy wywód. 
Inkluzja bywa ujmowana jako włączanie jednostki lub grupy społecznej do większej całości, np. dzieci ze specjalnymi potrzebami edukacyjnymi do szkół ogólnodostępnych lub grup zagrożonych wykluczeniem do uczestnictwa w życiu społeczności lokalnej. W moim przekonaniu jest to nadmierne zawężenie i osłabienie tej - rewolucyjnej w swych początkach - idei. Inkluzję rozumiem, podobnie jak Victor Lechta (2010, za: Ligus, 2012), Rozalia Ligus (2012) czy Roger Slee (2009), jako „poszerzanie przestrzeni publicznej na rzecz rzeczywistego, a nie pozorowanego realizowania praw człowieka” (Ligus, 2012). Jako rekonstrukcję myślenia o społeczeństwie, tak by odzwierciedlało ono różnorodne tożsamości swoich członków, stwarzało możliwości zaspokajania różnorodnych potrzeb i elastycznie na nie reagowało. Chodzi tu o zmianę paradygmatu myślenia, o fundamentalną przemianę świadomości.

Drugą kluczową kategorią jest globalne obywatelstwo. Jest to przy tym pojęcie wielowymiarowe i trudne do precyzyjnego zdefiniowania. By nie powtarzać rozważań definicyjnych, które zawarłam w innym miejscu (Kuleta-Hulboj, 2018a), ograniczę się do naszkicowania podstawowej charakterystyki tej kategorii.

Początkowo, w drugiej połowie lat 80. i początkach lat 90. XX wieku², miano globalnych obywateli odnosiło się do stosunkowo nielicznej grupy ludzi sprawnie poruszających się w świecie narastających globalnych zależności, powiązań ekonomicznych, politycznych i kulturowych, a także do aktywistów i liderów ruchów anty- czy alterglobalistycznych (Sant, Davies, Pashby, Shultz, 2018).

Z czasem - i zyskiwaniem popularności - globalne obywatelstwo zaczęło przybierać różne znaczenia i odwoływać się do odmiennych czasem podstaw filozoficznych czy ideologicznych. Pojawia się w różnych kontekstach i odmiennych dyskursach (por. Kraska, Bourn, Blum, 2018). W 2013 roku Laura Oxley i Paul Morris podjęli udaną próbę uporządkowania istniejących definicji globalnego obywatelstwa i wyróżnili 8 modeli składających się na dwa typy: kosmopolityczny i rzeczniczy (Oxley, Morris, 2018). To pokazuje, jak trudno zdefiniować globalnego obywatelstwo i jak różne założenia się za nim kryją.

Analizy różnorodnych działań z zakresu globalnej edukacji obywatelskiej wskazują, że globalne obywatelstwo najczęściej formułowane jest w perspektywie neoliberalnej lub liberalno-humanistycznej. W tej pierwszej optyce globalny obywatel to ktoś znakomicie przygotowany do stawiania czoła wyzwaniom światowej gospodarki i do rywalizacji na globalnym rynku. W drugiej perspektywie globalne obywatelstwo wiąże się z umiejętnością rozumienia złożoności współczesnego

2 Pomijam w tym miejscu jeszcze wcześniejsze filozoficzne konceptualizacje, wywodzące się od starożytności i kosmopolitycznego ideału „obywatela świata” (por. Wonicki, 2010). 
świata i swego miejsca w nim, a także zdolnością do obywatelskiego działania w tym świecie, w imię dobra wspólnego (por. Andreotti, 2011; Kraska, Bourn, Blum, 2018).

\section{GLOBALNA EDUKACJA OBYWATELSKA A INKLUZJA - UJĘCIE KRYTYCZNE}

Coraz częściej autorzy i autorki inspirowani teoriami krytycznymi i postkolonialnymi wskazują, że wiele działań z zakresu globalnej edukacji obywatelskiej to inkluzja pozorna, nieświadomie reprodukują one bowiem stereotypy, nierówności i zależności (Andreotti, 2016; Bryan, Bracken, 2011; Jefferess, 2008). Szczegółowo omówiłam tę krytykę w innym miejscu (Kuleta-Hulboj, 2018a), tutaj tylko podsumuję jej główne wątki.

Globalne obywatelstwo krytykowane jest za elitarność i tworzenie kolejnych wykluczeń, w swoich dominujących ujęciach ignoruje ono bowiem nierówności w dostępie do zasobów i władzy. Ponadto odnosi się przede wszystkim do mieszkańców zamożnej uprzywilejowanej Północy, którzy mają pieniądze, możliwości i wykształcenie pozwalające działać na rzecz naprawy świata (Jefferess, 2008).

Poza tym globalne obywatelstwo uwikłane jest w pułapkę napięć między uniwersalizmem a poszanowaniem różnic. Z jednej strony, uniwersalistyczne obietnice globalnego obywatelstwa - Dowerowskie „wszyscy jesteśmy globalnymi obywatelami” (Dower, 2008) - są pociągające w swej inkluzywności i rezygnacji z egzotyzacji. Wszak dominujące dyskursy globalnego Południa ucieleśniają proces różnicowania i czynienia obcym (Othering), czyli wyostrzania różnic między „my” a „oni”, a tym samym ustanawiania i podtrzymywania dystansu społecznego (Lister, 2008a). Uniwersalistyczne rozumienie globalnego obywatelstwa podkreślające wspólnotę całej ludzkości może ten dystans zmniejszać.

Z drugiej strony, jak wskazują liczne analizy krytyczne (Abdi, 2011; Andreotti, 2011; Melosik, 1994; Swanson, 2011), jest to uniwersalizm bynajmniej nie uniwersalistycznego ideału. Kategoria globalnego obywatelstwa zrodziła się i rozwijana jest przede wszystkim w krajach globalnej Północy, w kręgu kultury zachodniej, i w zasadzie nie włącza niezachodnich wartości, sposobów poznania i rozumienia świata. Jest przy tym traktowana tak, jakby była neutralna i rzeczywiście uniwersalna.

Kolejny zarzut dotyczy budowania obrazu mieszkańców globalnego Południa jako biernych, zależnych, godnych współczucia odbiorców pomocy płynącej ze strony zamożnego świata. Globalny obywatel jest w tym kontekście superbohate- 
rem, dobroczyńcą mniej uprzywilejowanej części ludzkości. W imię humanizmu i miłosierdzia aktywnie działa na rzecz poprawy warunków życia ludzi w odległych krajach, budując studnie, ucząc miejscowych nauczycieli bądź organizując pomoc rzeczową. Działa raczej dla Innych niż z nimi, podtrzymując swą uprzywilejowaną pozycję i pomijając jej historyczne i społeczno-kulturowe uwarunkowania (Jefferess, 2008; Kuleta-Hulboj, 2017).

Na jeszcze inne ograniczenia kategorii globalnego obywatelstwa, związane z redukowaniem go do wymiaru niezbędnych do opanowania kompetencji (Biesta, Lawy, 2006; Lawy, Biesta, 2006), wskazuję we wcześniejszych tekstach (Kuleta-Hulboj, 2018a; 2018b). Globalne obywatelstwo to nie status, który nabywa się w drodze edukacji, ale codzienna praktyka, procesy identyfikacji, realizacji i uczenia się go. Utożsamienie globalnego obywatelstwa z zestawem określonych treści i umiejętności, swoistym katalogiem dobrego globalnego obywatela, odsuwa je od codziennego życia, ignoruje aksjologiczny i empancypacyjny wymiar edukacji oraz produkuje kolejne nierówności i wykluczenia. Rodzi także pytania o źródła tego ideału; o to, kto, w czyim imieniu i na czyją korzyść w taki sposób definiuje globalne obywatelstwo (Pashby, 2014).

Wreszcie, wraz z rosnącą popularnością kategorii globalnego obywatelstwa pojawiły się obawy o to, że może ono zostać zinstrumentalizowane, zbanalizowane i pozbawione emancypacyjnego potencjału. I rzeczywiście, analizy prowadzone w różnych krajach globalnej Północy pokazują, że kategoria ta ulega neoliberalnemu przejęciu (Jefferess, 2008; Kraska, Bourn, Blum, 2018; Mannion et al., 2011; Swanson, 2011). Zamiast wspierania młodych ludzi w kształtowaniu umiejętności radzenia sobie z niepewnością, różnorodnością i złożonością współczesnego świata oraz podejmowania działań na rzecz inkluzji, solidarności i zmiany społecznej, liczne programy koncentrują się na przygotowywaniu ich do skutecznej rywalizacji na globalnym rynku pracy. Pomijają przy tym złożone, w tym także systemowe źródła marginalizacji i nierówności.

Biorąc pod uwagę tę krytykę, można uznać, że - wbrew deklaracjom i założeniom - inkluzywność globalnego obywatelstwa i związanej z nim globalnej edukacji obywatelskiej jest pozorna. Problematyczny okazuje się konstrukt globalnego obywatela - elitarny, imperialistyczny i paternalistyczny, a także ucieleśniający dyskurs neoliberalny. 


\section{KU INKLUZYWNEMU GLOBALNEMU OBYWATELSTWU}

Czy możliwe jest przezwyciężenie tych ograniczeń? I jak to zrobić? Jedną z możliwych dróg jest krytyczna edukacja globalna, o której szerzej piszę w innym miejscu (Kuleta-Hulboj, 2015; 2016). W tym artykule chciałabym się natomiast skoncentrować na zarysowaniu możliwości przeformułowania kategorii globalnego obywatelstwa w kierunku bardziej inkluzywnym.

Inspiracje znaleźć można nie tylko w krytycznych analizach globalnej edukacji obywatelskiej (o których piszę nieco dalej), ale również w studiach nad obywatelstwem, zwłaszcza w feministycznych analizach obywatelstwa czy koncepcjach obywatelstwa dzieci. Część postulatów z obu tych obszarów badawczych jest zresztą zbieżna.

W studiach nad obywatelstwem podkreśla się od pewnego czasu przemiany tradycyjnych powiązań między tożsamością, obywatelstwem a miejscem życia, zachodzące pod wpływem procesów globalizacyjnych (Gaventa, Tandon, 2010; Lister, 2007). Kwestionowane - jako niewystarczające - jest terytorialne rozumienie obywatelstwa. W zamian pojawiają się nowe formy myślenia o obywatelstwie, oderwane od miejsca lub operujące na różnych poziomach - od lokalnego, przez regionalny, narodowy po globalny (obywatelstwo kosmopolityczne, globalne, planetarne). Liczne studia podkreślają potrzebę uwzględniania w badaniach i w refleksji teoretycznej nietradycyjnych znaczeń, praktyk i doświadczeń obywatelstwa; potrzebę docierania do złożonych, nierzadko rywalizujących ze sobą sposobów pojmowania obywatelstwa; oraz rozwijania takich jego ujęć, które będą bardziej wrażliwe na wymiar temporalny, przestrzenny i relacyjny (Harris, Roose, 2014; Lister, 2003; 2007; Wood, 2014).

Jednym z kierunków poszukiwań jest zwrócenie uwagi na przeżywane obywatelstwo (lived citizenship). To kategoria odnosząca się do sensów i znaczeń, jakie obywatelstwo rzeczywiście ma w życiu ludzi, oraz sposobów, w jakie kontekst społeczny, kulturowy i materialny wpływa na ich życie jako obywateli (Lister, 2003; 2007). Ruth Lister odwołuje się do feministycznych analiz obywatelstwa oraz badań nad obywatelstwem osób ubogich, by pokazać, jak różnorodne podziały społeczne, takie jak klasa, płeć społeczno-kulturowa, rasa czy niepełnosprawność, zapośredniczają doświadczanie i praktykowanie obywatelstwa przez dorosłych i młodzież. Idąc tropem feministycznych modeli obywatelstwa zorientowanego na różnicę (difference-centred), podkreśla konieczność rekonceptualizacji kategorii obywatelstwa, by uwzględniało wielość tożsamości i pozycji zajmowanych przez podmioty oraz nie ograniczało się do sfery publicznej.

Lister odchodzi od homogenicznego, zerojedynkowego rozumienia obywatelstwa (albo jestem, albo nie jestem obywatelką) na rzecz pluralistycznej, zróżnico- 
wanej i inkluzywnej formuły. W jej ujęciu na inkluzywne obywatelstwo składają się cztery podstawowe elementy: członkostwo w społeczności (membership), związane także z poczuciem przynależności do wspólnoty i partycypacją; wynikające z tego członkostwa prawa (osobiste, polityczne i socjalne) oraz obowiązki (w sferze publicznej i prywatnej, zarówno polityczne, jak i społeczne); wreszcie równość statusu, poszanowania i uznania (equality of status, respect and recognition). Waga i znaczenie każdego z tych elementów mogą się różnić w zależności od kontekstu społecznego, politycznego i kulturowego - w jednym miejscu świata istotniejsza jest partycypacja, w innym - obywatelskie prawa i obowiązki (Lister, 2007). „Choć pojęcie obywatelstwa skonstruowane jest typowo, tzn. abstrakcyjnie i uniwersalnie, to jednak ów aspekt uniwersalny ujęty zostaje i wyrażony w specyficznie narodowym kontekście społecznym i politycznym, odzwierciedlając tym samym historyczne i prawne tradycje oraz instytucjonalne i kulturowe kompleksy. Co znaczy dla nas być obywatelem, jakich słów używamy dla wyrażenia tych znaczeń - wszystkie te żywe doświadczenia mogą poza tym przybierać niezwykle zróżnicowaną postać” (Lister, 2008b, s. 26).

Charakteryzując aksjologiczny fundament inkluzywnego obywatelstwa Lister przywołuje wnioski z książki Inclusive Citizenship: Meanings and Expressions pod redakcją Naili Kabeer (2005, za: Lister, 2007). Na podstawie analiz studiów przypadku realizowanych między innymi w krajach globalnego Południa, Kabeer wyłoniła 4 wartości inkluzywnego obywatelstwa. Należą do nich: sprawiedliwość, uznanie, samostanowienie oraz solidarność. Sprawiedliwość rozumiana jest przez osoby uczestniczące w badaniach nie jako jednakowe traktowanie, ale jako dążenie do osiągnięcia rzeczywistej równości, które czasem wymaga zróżnicowanego traktowania. Uznanie odnosi się do przyrodzonej i niezbywalnej wartości wszystkich ludzi i poszanowania różnic między nimi. Samostanowienie polega na zdolności do kontrolowania swojego życia, jest to ujęcie zbieżne z konceptualizacjami obywatelstwa osób niepełnosprawnych (por. Żyta, 2013). Wreszcie solidarność, którą Kabeer rozumie za uczestnikami i uczestniczkami swoich badań jako „zdolność do identyfikacji z innymi i działania w jedności z nimi na rzecz sprawiedliwości i uznania” (Kabeer, 2005, za: Lister, 2007, s. 51).

Zasygnalizowane powyżej kierunki poszukiwań są inspirujące także dla myślenia o globalnym obywatelstwie. Pisząc o inkluzywnym obywatelstwie, Lister nierzadko odnosi się także do nierówności między globalną Północą a Południem, do wielości perspektyw i sposobów rozumienia świata, do napięć między poszanowaniem różnicy a uniwersalizmem obywatelstwa. Uwzględnia złożone i wielowarstwowe powiązania między wymiarem lokalnym a globalnym - na przykład w analizach globalnych łańcuchów opieki (global care chains), obywatelstwa 
ekologicznego czy ubóstwa w krajach globalnego Południa. Są zagadnienia istotne także w kontekście globalnego obywatelstwa.

Również wyłonione przez Kabeer wartości inkluzywnego obywatelstwa z powodzeniem można odnieść do globalnego obywatelstwa. Kabeer pokazuje, jak z punktu widzenia samych wykluczonych wygląda, co oznacza i jak jest osiągane inkluzywne obywatelstwo. Jak stwierdza, „te wartości wyrażają także ich (podkreśl. MKH) wizję bardziej włączającego społeczeństwa” (2005: 3, za Lister, 2007, s. 50). Jest to przejaw włączania perspektyw globalnego Południa i ludności rdzennej, do czego nawołują między innymi Vanessa Andreotti (Andreotti, Ahenakew, Cooper, 2011; Andreotti, de Souza, 2008), Ali A. Abdi (2011; 2015) czy Lynette Shultz (2011). To także jeden z warunków przezwyciężenia fałszywego uniwersalizmu i hegemonii zachodniego sposobu rozumienia globalnej edukacji obywatelskiej i globalnego obywatelstwa. Chodzi nie tylko o oddolne budowanie pewnego ideału i uwzględnianie wartości preferowanych przez jednostki i grupy zagrożone wykluczeniem, ale także o włączenie różnych epistemologii i sposobów poznawania świata, o „sprawiedliwość poznawczą” (Shultz, 2011).

Także Lister upomina się o „prawo różnych form wiedzy do współistnienia i współkształtowania decyzji mających wpływ na ludzkie życie” (knowledge rights) (Leach and Scoones, 2003, za Lister, 2008a, s. 10). Dzięki temu możliwe jest poszerzenie naszych horyzontów rozumienia, oglądu i doświadczania świata. $\mathrm{Na}$ przykład, jak zauważa Namrata Sharma (2018, s. 43), pisząc o globalnej edukacji obywatelskiej: „alternatywne sposoby myślenia o innych i o relacjach z innymi mogą uzupełnić obecne zainteresowanie edukacji indywidualnym upodmiotowieniem o wartość wspierania w rozwoju do wartościowego życia i troski o dobro wspólne”.

Należy przy tym pamiętać, że inkluzywne obywatelstwo może znaczyć coś innego dla różnych grup. Lister pisze w tym kontekście o kobietach i młodzieży - ich stosunek do obywatelstwa jest zapośredniczony nie tylko przez płeć kulturową czy wiek, ale i przez status społeczno-ekonomiczny, etniczność, (nie) pełnosprawność i inne ważne zmienne tożsamościowe/statusowe (Lister, 2007). Włączenie perspektywy płci kulturowej pozwala dostrzec zarówno ograniczenia tradycyjnie ujmowanego obywatelstwa, jak i możliwości jego redefinicji. Lister przeformułowuje obywatelstwo jako nie ograniczające się do sfery publicznej, ale realizowane i praktykowane także w sferach prywatnych, w domu, gospodarstwie i społeczności lokalnej. Tezy te odnoszą się w moim przekonaniu także do globalnego wymiaru obywatelstwa, który mediowany jest przez podobne czynniki. Inne znaczenia wiążą z nim migrantki ekonomiczne z krajów Południa opiekujące się dziećmi w zamożnych rodzinach globalnej Północy (por. Lister, 2007), inaczej 
rozumieją je osoby z niepełnosprawnością, pragnące wziąć udział w programach wolontariatu zagranicznego, doświadczające wykluczenia z globalnego obywatelstwa przez tę niepełnosprawność.

Jak w dążeniu do możliwie pluralistycznego ujęcia globalnego obywatelstwa nie zgubić tego, co w uniwersalizmie jest dobre (np. uniknięcie egzotyzacji i widzenie w drugim człowieka należącego do wspólnoty ludzkiej)? Pytanie nie jest nowe. Lister rozwiązuje te napięcia dzięki kategorii „zróżnicowanego uniwersalizmu” (differentiated uniwersalism), czyli uniwersalizmu wrażliwego na różnice. Oznacza to, że prawa i obowiązki obywatelskie nie muszą, a nawet nie powinny być identyczne dla wszystkich. Celem bowiem nie jest osiągnięcie równości formalnej, tylko równość rzeczywista - a ta wymaga czasem zróżnicowanego traktowania.

Podobne inspiracje można znaleźć także w tekstach Sharon Todd (2009), filozofki edukacji, która - za Judith Butler - proponuje procesy kulturowej translacji wszystkich roszczeń do uniwersalności, takich jak prawa człowieka czy tzw. wartości ogólnoludzkie. Todd traktuje je jako otwarte, warunkowe i zależne od kontekstu kulturowego, historycznego i politycznego; jako wyrażane w określonych systemach reprezentacji i dlatego wymagające nieustannego przekładania na inne języki i systemy znaczeń.

\section{IMPLIKACJE DLA EDUKACJI}

Z dotychczasowych rozważań można wyprowadzić kilka ważnych wniosków dla globalnej edukacji obywatelskiej, która pełni istotną rolę w kształtowaniu globalnych obywateli i obywatelek.

Po pierwsze, by przygotowywać do możliwie pełnej realizacji inkluzywnego i emancypacyjnego potencjału, globalna edukacja obywatelska powinna odważnie stawiać czoła tym (zasygnalizowanym wyżej) elementom czy wymiarom globalnego obywatelstwa, które mają charakter wykluczający. Chodzi o krytyczne analizy samego ideału globalnego obywatela, pytania o istotę inkluzji, o to, kto, w czyim imieniu, dla czyjego dobra i na czyich warunkach ją realizuje (Lister, 2007; Pashby, 2014).

Po drugie, inkluzywna globalna edukacja obywatelska nie tylko powinna brać pod uwagę różne stanowiska i punkty widzenia, różne sposoby poznawania świata i rozumienia swojego miejsca w nim (Abdi, 2011; 2015; Andreotti, de Souza, 2008; Bourn, 2016), ale pójść dalej - dziać się na warunkach osób i grup wykluczonych.

Po trzecie, ważny jest kontekst, w którym odbywa się ta edukacja. Określona społeczność lokalna, szkoła i zespół klasowy stanowią cenny zasób dla działań 
edukacyjnych. Inkluzywnie rozumiana globalna edukacja obywatelska powinna bowiem wyrastać z kontekstów lokalnych i sięgać szerzej, ku wymiarom globalnym. Mam tu na myśli włączanie perspektywy osób uczących się, uczynienie punktem wyjścia tego, co one same rozumieją pod pojęciem globalnego obywatela czy aktywności obywatelskiej na poziomie globalnym, wspólne eksplorowanie różnic kulturowych i związanych z nimi codziennych wyzwań w klasie (np. jak poznawać i szanować odmiennych od nas, jak radzić sobie z konfliktami) etc. Klasa szkolna może stanowić przestrzeń eksperymentowania z tymi kluczowymi wątkami i przestrzeń praktykowania globalnego obywatelstwa (Tarc, 2011). Może być areną doświadczania i radzenia sobie - w bezpiecznych warunkach - z trudnościami wiążącymi się z pluralizmem i odmiennością (Todd, 2009).

\section{ZAKOŃCZENIE}

Globalna edukacja obywatelska wraz z ogłoszeniem przez ONZ „Agendy na rzecz zrównoważonego rozwoju 2030” stała się ważnym narzędziem realizacji Celów Zrównoważonego Rozwoju. Jednym z jej zadań w ujęciu UNESCO jest przygotowanie dzieci, młodzieży i dorosłych do budowy bardziej inkluzywnego świata. Krytycy wskazują jednak, że globalna edukacja obywatelska często zawodzi i z różnych powodów bywa to inkluzja pozorna. Jednym z nich jest sama kategoria globalnego obywatelstwa wytwarzająca nowe wymiary wykluczenia, krytykowana między innymi za elitaryzm, imperializm i paternalistyczne traktowanie globalnego Południa.

W artykule zarysowałam jedną z możliwych dróg przezwyciężenia tych ograniczeń i realizacji inkluzywnego potencjału globalnej edukacji obywatelskiej, czyli redefinicję kategorii globalnego obywatelstwa. Inspirując się pracami Ruth Lister i krytycznymi analizami globalnej edukacji obywatelskiej, wskazałam na potrzebę bardziej elastycznej, pluralistycznej formuły globalnego obywatelstwa, wrażliwego na różnicę, ale nie rezygnującego z uniwersalistycznych obietnic. Dzięki proponowanemu rozumieniu globalnego obywatelstwa być może uda się uniknąć hegemonii, imperializmu i starych-nowych wykluczeń. 


\section{Bibliografia}

Abdi, A.A. (2011). De-monoculturalizing global citizenship education: the need for multicentric intentions and practices. W: L. Shultz, A.A. Abdi, G.H. Richardson (eds.), Global citizenship education in post-secondary institutions: Theories, practices, policies (s. 25-39). New York: Peter Lang Publishing, Inc.

Abdi, A.A. (2015). Decolonizing Global Citizenship Education. W: A.A. Abdi, L. Shultz, T. Pillay (eds.), Decolonizing global citizenship education (s. 11-26). Rotterdam: SensePublishers. DOI: 10.1007/978-94-6300-277-6_2.

Andreotti, V. (2011). Actionable postcolonial theory in education. Postcolonial studies in education. New York: Palgrave Macmillan.

Andreotti, V. (2016). The educational challenges of imagining the world differently. Canadian Journal of Development Studies / Revue canadienned'études du développement, 37(1), s. 101-112. DOI: 10.1080/02255189.2016.1134456.

Andreotti, V., Ahenakew, C., Cooper, G. (2011). Epistemological pluralism. Ethical and pedagogical challenges in higher education. AlterNative: An International Journal of Indigenous Peoples, 7(1), s. 40-50.

Andreotti, V., de Souza, L.M. (2008). Learning to read the world Through Other Eyes. Derby: Global Education.

Biesta, G., Lawy, R. (2006). From teaching citizenship to learning democracy: overcoming individualism in research, policy and practice. Cambridge Journal of Education, 36(1), s. 63-79. DOI: 10.1080/03057640500490981.

Bourn, D. (2016). Global citizenship and youth participation in Europe. Research report. Pobrane z: https://policy-practice.oxfam.org.uk/publications/global-citizenship-andyouth-participation-in-europe-605919.

Bryan, A., Bracken, M. (2011). Learning to read the world? Teaching and learning about global citizenship and international development in post-primary schools. Dublin: Identikit, Irish Aid.

Dower, N. (2008). Are we all global citizens or are only some of us global citizens? The relevance of this question to education. W: A.A. Abdi, L. Shultz (eds.), Educating for Human Rights and Global Citizenship (s. 39-54). New York: State University of New York Press.

Gaventa, J., Tandon, R. (eds.). (2010). Globalizing citizens: new dynamics of inclusion and exclusion. London-New York: Zed Books.

Harris, A., Roose, J. (2014). DIY citizenship amongst young Muslims: experiences of the 'ordinary'. Journal of Youth Studies, 17(6), s. 794-813. DOI:10.1080/13676261.201 3.844782.

Jefferess, D. (2008). Global citizenship and the cultural politics of benevolence. Critical Literacy: Theories and Practices, 2(1), s. 27-36.

Kraska, M., Bourn, D., Blum, N. (2018). From internationalization to global citizenship: Dialogues in international higher education. W: J.P. Davies, Pachler N. (eds.), Teaching and learning in higher education: Perspectives from UCL (s. 85-98). London: UCL IOE Press.

Kuleta-Hulboj, M. (2015). Postkolonialna edukacja globalna w działaniu: inicjatywy Open Spaces for Dialogue and Enquiry i Through Other Eyes. W: M. Kuleta-Hulboj, 
M. Gontarska (red.), Edukacja globalna: Polskie konteksty i inspiracje. Wrocław: Wydawnictwo Naukowe Dolnośląskiej Szkoły Wyższej; Instytut Globalnej Odpowiedzialności.

Kuleta-Hulboj, M. (2016). Wybrane koncepcje edukacji globalnej. W: Z. Babicki, M. Kuleta-Hulboj (red.), Teoretyczne i praktyczne konteksty edukacji globalnej (s. 61-82). Warszawa: Wydawnictwo Uniwersytetu Kardynała Stefana Wyszyńskiego.

Kuleta-Hulboj, M. (2017). Krytyczna Analiza Dyskursu edukacji globalnej w wybranych materiałach organizacji pozarządowych (z warsztatu badawczego). W: D. Kubinowski, M. Chutorański (red.), Seminaria Metodologii Pedagogiki / Polskie Towarzystwo Pedagogiczne. Pedagogika jako humanistyczno-społeczna nauka stosowana: Konsekwencje metodologiczne (s. 265-276). Kraków: Oficyna Wydawnicza Impuls.

Kuleta-Hulboj, M. (2018a). Inkluzja z perspektywy globalnej edukacji obywatelskiej. W: G. Dryżałowska, M. Kuleta-Hulboj, A. Naumiuk, M. Skura, A. Steinhagen, Inkluzja w perspektywie pedagogiki specjalnej i pedagogiki społecznej. Pytania, konteksty, dyskusje (s. 98-124). Warszawa: Wydawnictwo Uniwersytetu Warszawskiego.

Kuleta-Hulboj, M. (2018b). O potrzebie utopijnej, radykalnie etycznej edukacji globalnej. Pedagogika Społeczna, (67)1, s. 39-55.

Lawy, R., Biesta, G. (2006). Citizenship-as-Practice: The Educational Implications of an Inclusive and Relational Understanding of Citizenship. British Journal of Educational Studies, 54(1), s. 34-50. DOI: 10.1111/j.1467-8527.2006.00335.x.

Ligus, R. (2012). Pedagogika inkluzji i zarządzanie piętnem - znaczenia, interpretacje, praktyki. W: P. Rudnicki, M. Starnawski, M. Nowak-Dziemianowicz (red.), Władza, sens, działanie: studia wokół zwiq̨zków ideologii i edukacji (s. 309-330). Wrocław: Wydawnictwo Naukowe Dolnośląskiej Szkoły Wyższej.

Lister, R. (2003). Citizenship: Feministperspectives. 2nd ed. Basingstoke-Hampshire-New York: Palgrave Macmillan.

Lister, R. (2007). Inclusive Citizenship: Realizing the Potential. Citizenship Studies, 11(1), s. 49-61. DOI: 10.1080/13621020601099856.

Lister, R. (2008a). Inclusive Citizenship, gender and poverty: some implications for education for citizenship. CitizenshipTeaching and Learning, 4(1), s. 3-19.

Lister, R. (2008b). Od intymności do globalności: refleksje nad płciowym wymiarem obywatelstwa. W: E. Oleksy (red.), Tożsamość i obywatelstwo w świecie wielokulturowym. Warszawa: Wydawnictwo Naukowe PWN.

Mannion, G., Biesta, G., Priestley, M. i Ross, H. (2011). The global dimension in education and education for global citizenship: genealogy and critique. Globalisation, Societies and Education, 9(3-4), s. 443-456. DOI: 10.1080/14767724.2011.605327.

Melosik, Z. (1994). Edukacja globalna: nadzieje i kontrowersje. W: H. Kwiatkowska (red.), Ewolucja tożsamości pedagogiki (s. 165-176). Warszawa: IHNOiT.

ONZ. (2015). Przekształcamy nasz świat: Agenda na rzecz zrównoważonego rozwoju 2030. Pobrane z: http://www.unic.un.org.pl/files/164/Agenda\%202030_pl_2016_ostateczna. pdf.

Oxley, L., Morris, P. (2013). Global Citizenship: A Typology for Distinguishing its Multiple Conceptions. British Journal of Educational Studies, 61(3), s. 1-25. DOI: 10.1080/00071005.2013.798393. 
Pashby, K. (2014). Questions for global citizenship education in the context of the 'new imperialism’: For whom, by whom? W: V. Andreotti, L.M.T. De Souza (eds.), Postcolonial perspectives on global citizenship education (s. 9-26). Abingdon-New York: Routledge.

Sant, E., Davies, I., Pashby, K., Shultz, L. (2018). Global citizenship education: A critical introduction to key concepts and debates. New York: Bloomsbury Academic.

Sharma, N. (2018). Global Citizenship Education and Non-Western Perspectives. W: N. Sharma (ed.), Value-Creating Global Citizenship Education: Engaging Gandhi, Makiguchi, and Ikeda as Examples (s. 43-55). Cham: Springer International Publishing. https://doi.org/10.1007/978-3-319-78244-7_3.

Shultz, L. (2011). Engaging the multiple discourses of global citizenship education within a Canadian university: deliberation, contestation, and social justice possibilities. W: L. Shultz, A.A. Abdi, G.H. Richardson (eds.), Global citizenship education in post-secondary institutions: Theories, practices, policies (s. 13-24). New York: Peter Lang Publishing, Inc.

Slee, R. (2009). The Inclusion Paradox: The Cultural Politics of Difference. W: M.W. Apple, W. Au, L.A. Gandin (eds.), Routledge international handbook series. The Routledge international handbook of critical education (s. 177-189). New York-London: Routledge.

Swanson, D.M. (2011). Parallaxes and paradoxes of global citizenship: Critical reflections and possibilities of praxis in/through an international online course. W: L. Shultz, A.A. Abdi, G.H. Richardson (eds.), Global citizenship education in post-secondary institutions: Theories, practices, policies (s. 120-139). New York: Peter Lang Publishing, Inc.

Tarc, P. (2011). Bridging (representations of) the "Global Present” with the life-world of the classroom: researching toward "learning to teach" global citizenship education. W: L. Shultz, A.A. Abdi, G.H. Richardson (eds.), Global citizenship education in post-secondary institutions. Theories, practices, policies (s. 64-75). New York: Peter Lang Publishing, Inc.

Todd S., (2009). Toward an imperfect education. Facing humanity, rethinking cosmopolitanism, Boulder: Paradigm Publishers.

UNESCO. (2014). Global citizenship education: preparing learners for the challenges of the 21st century. Paris: UNESCO.

Wonicki, R. (2010). O potrzebie kosmopolitycznego obywatelstwa. Zoon Politikon, 1, s. 73-83. Pobrane z: http://polona.pl/item/32457299.

Wood B. (2014). Researching the everyday: young people's experiences and expressions of citizenship. International Journal of Qualitative Studies in Education, 27(2), s. 214-232. DOI: https://doi.org/10.1080/09518398.2012.737047.

Żyta, A. (2013). Samostanowienie dorosłych osób z niepełnosprawnością intelektualną we współczesnej Polsce - pozory czy rzeczywistość? Człowiek - Niepełnosprawność - Społeczeństwo, 4(22), s. 117-130. DOI: 10.5604/17345537.1104006. 